\title{
Integrated Model for Understanding and Enhancing Green Purchase Behavioral Intention:
}

\section{Directions for Future Research}

\author{
Velnampy T. \\ Professor, Faculty of Management Studies and Commerce \\ University of Jaffna, Sri Lanka \\ Email: tvnampy@yahoo.co.in
}

\author{
Achchuthan Sivapalan (Corresponding author) \\ M. Phil Scholar, Faculty of Graduate Studies \\ University of Jaffna, Sri Lanka \\ Email: achchu2009@gmail.com
}

Received: April 12, 2016 Accepted: May 24, 2016 Published: June 27, 2016

doi:10.5296/jsr.v7i1.9541 URL: http://dx.doi.org/10.5296/jsr.v7i1.9541

\begin{abstract}
Environmental management and protection take prominent place in the globe, where environmental pollution already stressed the bio - diversity. In Globalized level, policy makers, marketers and general public also pronounce environmental protection and its benefits. In line with above arguments, green marketing was selected as theme to ground the research. In the green marketing paradigm, green consumerism was selected as the main theme. In line with above facts, the integrated conceptual model was developed to predict the purchase intention and behavior towards green products. Altogether, seven antecedents as environmental attitude, environmental concern, perceived consumer effectiveness, health consciousness, social influence, media influence and perceived government initiatives were incorporated in to the proposed model. Therefore, the proposed model is considered as the comprehensive one to predict the intention towards green products. Further, this model can be applied in globalized level among consumers to predict the purchase intention and behavior towards green products.
\end{abstract}

Keywords: Green Consumerism, Green Purchase Intention and Integrated Model 


\section{Introduction}

Resources are limited and human wants are unlimited in the planet. Therefore, it is important for the marketers to utilize the resources effectively and efficiently without having waste as well as to achieve the organizational objectives (Chan \& Lau, 2000; Kim \& Choi, 2005; Peattie\& Cane, 2005 and Lee, 2008). In this context, green marketing and its influence on buyer behavior have the strategic role in the green consumerism. Based on the criteria, there is a paucity of research on the green issues in the marketing research and its practices. In recent years, the topic of green consumerism with sustainability has been captured and initiated by researchers and practitioners with unprecedented attention in both developed and emerging countries.

Today, environmental issues are viewed as the pressing problems among many consumers, policy makers, environmentalists, government and non-government bodies. In this aspect, the practice of green marketing and the theme as "Going green" are extending to the globalized level, where environmental threats are damaging the welfare of the society and citizens (Samarasinghe, 2012 a). In the globalized context, emerging countries started to initiate the environmental issues as the major concern in the recent decade. Meantime, their environment quality legs far behind when compared to the developed countries. Further, Johri and Sahasakmontri (1998) and Lee (2008) note that, government policies and business strategies in many Asian countries are being reshaped to give more consideration for long-term sustainable development including environmental protection. In the supportive view, Samarasinghe (2012 a) documents that developing countries' recent trend with regard to environmental issues are in the green awakening stage. Environmental forum on 'greening the economy' and the environmental education programs for every levels of the countries have been initiated by the governmental bodies. Further, counties in Asia aspire to motivate people to choose healthy/organic food products, reduce pollution through new regulations and environmentally safe consumption as less carbon emission.

Based on the overall picture of the green issues and its trend in Asian and South Asian countries, empirical study on green consumerism is much needed to get the new cues on the subject of the green purchase intention and behavior. Due to that, this study is directed to assess the green purchase intention. In this stance, young consumers are selected as the potential respondents, who have tremendous knowledge about green management and marketing as the new emerging concept. young consumers who are innovative, dynamic, smart, daring, efficient, determined, modern and employable or in one word, back bone of the nations and, they have the future potential to influence in policy making and its practices with regard to socio, economic, politic \& legal and environmental aspects. In line with above mentioned statements, this is the time to empirically assess the green purchase intention among young consumers. The findings or understandings of the study aid to enhance the green marketing culture among young consumers. Based on the overall underpinned reasons, there is an urgent need to develop the comprehensive model for green purchase behavioral intention among young consumers especially in Asian region to predict the intention towards preference of green products. Researchers in this study strongly believe that, strong intention lead to behavior perfectly. In contrast, study findings reveal some interesting aspects that 
green consumer behavior is not influenced by the intention, in other words, green purchase intention doesn't provide the path for behavior due to the difficulties in terms of individuality, responsibility and practicality ( Ohtomo \& Hirose , 2007). In this context, researchers in this study attempted to develop the comprehensive model to predict the green purchase intention by incorporating the unique factors through Theories and Models in the green consumerism. Integrating unique dimensions might predict the green purchase intention strongly, which in turn lead behavior. In this way, gap between green purchase intention and behavior might be resolved by incorporating the above unique factors as the potential determinates of green purchase intention.

\section{Theoretical Background: Underpinning Theories of Green Purchase Intention}

This section is directed towards theories and approaches of the green marketing, consumer behavior and green purchase intention \& behavior, which give basic direction to construct the model for the study. Importantly, this part explicates 1) Green Marketing Strategy: Stake holder theory Perspective, which initiates the research problem on the ground of holistic approach. Under the stakeholder theory, consumers, competitors, government and NGOs, investors, supply chain partners, employees and society are concentrated and studied systematically. 2) Model of Consumer Behavior, which is investigated in the light of marketing environment, buyers' characteristics and buyers' decision process to understand the consumerism. 3) Theory of Reasoned Action and Planned Behavior, which is aimed at explaining the value - attitude- intention - behavior relationship especially in green marketing concept with respect to consumer behavioral research. Further, Theory of Planned Behavior elucidates the facts that, high accuracy from attitudes toward the behavior, subjective norms and perceived behavioral control able to predict the intentions to perform behaviors of different kinds; and these intentions together with perceptions of behavioral control account for considerable variance in actual behavior. 4) Finally, Altruism and Pro-Social Behavioral Theory is utilized to explicate the facts that personal norms are a key determinant that bridges the value action gap as a moral obligation go beyond the behavioral intention and activates the actual behavior.

\subsection{Green Marketing Strategy: Stake holder Perspective}

According to the stake holder theory, organizations should conduct the business beyond the base consideration of only making a profit. In this way, while executives and board of directors take the decision, they should consider the needs of divergent groups of relevant stakeholders as consumers, competitors, government and NGOs, investors, supply chain partners, employees and society (Freeman, 1984). And theory also suggests that, benefits concerning firm performance (Return on Investment and Assets), Market Performance (Market Share and growth), social (Community development and welfare) and environment (eco-friendly) should be strategically framed and implemented successfully especially in the hypercompetitive environment by every organizations. To be consistent with this scenario, Cronin et al. (2011) develop the model, which is represented as green marketing strategy in the stake holder theory, and gives the potential research opportunities to the marketing scholars concerning green performance, green strategies and green consumerism. 


\section{Macrothink Institute ${ }^{T M}$}

Based on the model, three concepts in the management as marketing, business management and operation are considered and focused to identify the facts, which are related to green issues. In this context, researchers recommend the potential research areas as green performance, green issues in supply chain management, green alliances, green issues in the production process and also green purchase behavior to investigate the green marketing as the strategic tool. Further, investigated model identifies both internal and external components to focalize the relevant reviews, which are related to the management, marketing and operation. In addition, the internal components of the model is developed to demonstrate the inter-connected nature of the core business disciplines of marketing, management (both strategy and human resources), and operations, which can be directly controlled by the firms. Meanwhile, the external portion highlights all the relevant stakeholders as customers, investors, suppliers, government and non-government, which can't be controlled directly by the firms.

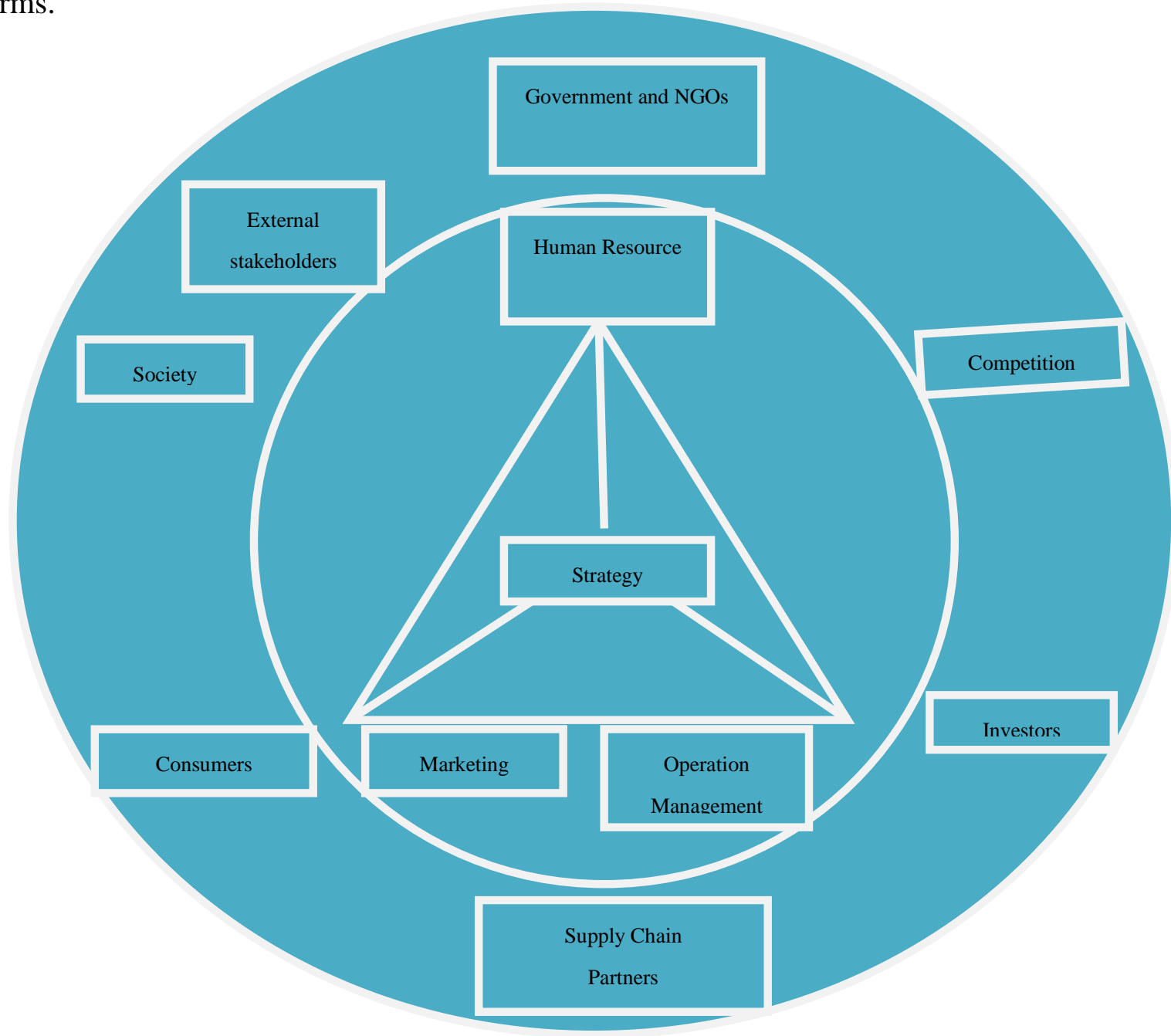

Figure 01: Green Marketing Strategy: Stake holder Perspective

Source: Cronin et al. (2011), Green Marketing Strategy: Stake holder Perspective 


\subsection{Consumer Behavior: Theory of Consumer Behavior in Marketing Domain}

Stake holder theory covers and investigates the parties, who are interested with particular organization. Stake holder theory is broad in theoretical and practical scenario. Even though, it highlights that customers in the interested parties should be considered as the key element in the business activities and its success. Further, customers or consumers are also considered and recognized as the most valuable assets in the world of marketing.

Marketing should identify and satisfy the target customers' needs and wants. Due to that, the field of consumer behavior takes the important place among scholars and industrialists to study how individuals, groups and organizations select, buy, use and dispose of goods, services, ideas or experiences to satisfy their needs and desires. Understanding consumer behavior is complex, it depends on various factors as (1) Marketing Stimuli (Product, price, place and promotion), (2) Other Stimuli (Economic, Technological, Political and Environmental factors), (3) Personal and psychological factors of buyers (Personality, Learning, Motivation etc). Those factors directly and indirectly influence the buyer decision making process (Kotler\& Armstrong, 2013).

Based on the aforementioned view points, this study investigates the factors influencing on purchase behavioral intention in the light of green consumerism. Studies on green consumerism differ from general consumerism. Generally, cost and benefits of the products and services are assessed by consumers. Individual benefits are considered as the key fact, while, cost also is associated with benefits to measure the customer value creation. In contrast, both individual and social benefits relating to environmental concern $\&$ attitude, nature $\&$ its future and resource allocation are renowned as the key elements in the green consumerism ( Kotler \& Keller, 2006 and McCarty \& Shrum, 2001). In line with this, green purchase behavioral intention is investigated in this study, which gives the different path or direction to focus on the social benefits and long term sustainability through the green consumerism.

\subsection{Green Purchase Intention and Underpinning Theories}

Especially in the motivational factor, intention is considered as the powerful predictor to influence the behavior ultimately. It means that, how hard people try to put the effort to perform the behavior. In other words, how much of an effort people are planning to exercise or how hard people are willing to perform the behavior. Based on the Ajzen (1991), the people who have the strong intention, they are more likely to perform their behavior. It means that strong intention leads to the behavior favorably. In this aspect, when customers show the strong intention toward the green product, they are more likely transcended to perform the actual purchase.

Environmental awareness among consumers becomes the major topic, which pledges the scholars and researchers to focalize the research on green purchase intention and behavior. In line with this, the theories like the Theory of Reasoned Action (TRA), Theory of Planned Behavior (TPB) and Altruism \& Pro-Social Behavior Theories are utilized by the researchers in the field of green consumerism to investigate the green purchase intention (Chan , 2001; Moe, 2007 and Samarasinghe, 2012 b). 


\section{Macrothink}

\subsubsection{Theory of Planned Behavior (TPB)}

In 1991, Ajzen framed the Theory of Planned Behavior as the extended model, which was developed as the extension of the theory of reasoned action. Theory explains that high accuracy from attitudes toward the behavior, subjective norms and perceived behavioral control able to predict the intentions to perform behaviors of different kinds; and these intentions, together with perceptions of behavioral control, account for considerable variance in actual behavior

The Theory of Planned Behavior (Ajzen, 1991) presents intention dependent upon three factors: (1) The individual's attitude toward the behavior (2) Subjective norm and (3) Perceived behavioral control.

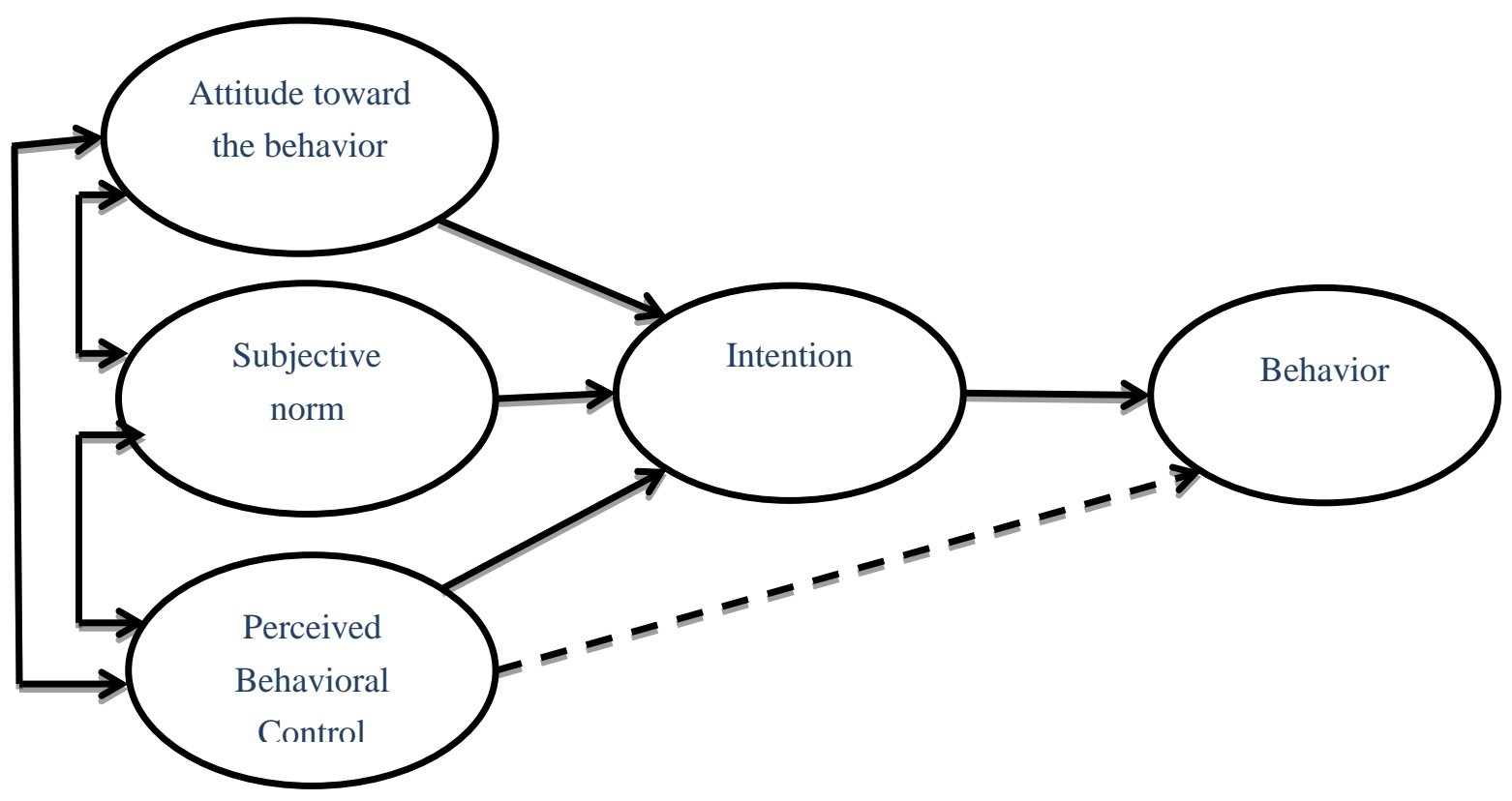

Figure 02: Theory of Planned Behavior

Source: Ajzen (1991), Theory of Planned Behavior

\section{Attitude}

Attitude towards performing behavior refers to perceptions of personal desirability to perform the behavior (Ajzen, 1991). It depends on the expectations and beliefs about personal impacts of outcomes resulting from the behavior.

\section{Subjective Norm}

The TPB holds that subjective norm is a function of beliefs. If a person believes that his or her referents think that behavior should be performed, then the subjective norm will influence his or her intention to perform that particular behavior. The referents here refer to a group of people who are close to the individual, for instance family, peers, spouse, close friend, teachers and anyone considered important in the individual's life (Ariff et al.,2010). 


\section{Perceived Behavior Control}

Perceived behavior control reflects the perceived ability to execute target behavior (Ajzen,1991). It relates to an individual's perception on the degree of easiness and difficulties in performing such behavior, and it is assumed to reflect past experience as well as anticipated obstacles (Ajzen\& Driver, 1992). This construct is affected by perceptions of access to necessary skills, resources and opportunities to perform the behavior. If an individual feels that he or she has control over the situational factors, he or she may develop the intention to perform the particular behavior. On the other hand, if an individual does not have control over the circumstances, he or she might have less intention to perform the particular behavior. Therefore, we can point that perceived behavior control influences intention to perform a behavior.

\section{Theory of Planned Behavior and Green Purchase Behavioral Intention}

Theory of Planned Behavior has been used in numerous studies in the consumer behavior towards green issues (Aertsens et al., 2009 and Arvola et al., 2008). In this way, based on thetheory of planned behavior, Moe (2007) focuses the study on sustainability, study defines the green purchase intention as "selectively choosing products with less environmental impact when purchasing goods", which mean green consumer tend to purchase green product to reduce the harmful of environment. In addition, green purchase intention is defined as the probability and willingness of a person, which are directed to purchase the eco-friendly products over non green products in their purchase decisions. Further than, Beckford et al. (2010) explore that green purchase intention is a considerable predictor of purchase behavior towards green consumerism; it denotes that purchase intention is positively associated with the probability of a customer decision that he will buy green products. In the supportive way, Chan (2001) points that environmental concern is highly associated with intention which will lead to behavior towards green aspects finally.

In contrast, study findings of Ohtomo and Hirose (2007) reveal some interesting aspects that green consumer behavior is not influenced by the intention, in other words, green purchase intention doesn't provide the path for behavior. A person hold the environmental concern and knowledge doesn't put the effort to purchase green products, which issues are called or named as value - action gap. It means that, although the customers show the intention to purchase the green product, but they are not in the position to perform the actual performance.

In line with above arguments, researchers in this study attempted to develop the comprehensive model to predict the green purchase intention by incorporating the unique factors as environmental attitude, environmental concern, perceived consumer effectiveness, health consciousness, social influence, media influence and perceived government initiatives. Integrating those unique dimensions might predict the green purchase intention strongly, which in turn lead behavior. In this way, gap between green purchase intention and behavior might be resolved by incorporating the above unique factors as the potential determinates of green purchase intention. 


\section{Macrothink}

\subsection{Altruism and Pro-Social Behavior}

Models of altruism and pro-social behavior are considered as the prominent conceptual framework to discuss the pro environmental behavior. In which, "Pro-Social" is defined as "Voluntary intentional behavior that results in benefits for others, the motive is unspecified and may be positive, negative or both" (Eisenberg \& Miller, 1987). In this view, altruism is a subset of pro-social behavior and scholars frame their models and assumptions based on theories of altruism claiming that altruism is as key feature for supporting pro-environmental behavior (Samarasinghe, 2012 b). Further, this theoretical framework has two assumptions: 1) Person with a strong selfish and competitive orientation are less likely to act pro environmental behavior (Pro-self); 2) People who satisfy their personal needs are more likely to act pro-environmental behavior, because they have more resources (time, money and energy) to care about bigger pro-environmental issues (Samarasinghe, $2012 \mathrm{~b}$ ) .

Under the Altruism and Pro-Social Behavior Theories, two models as Norm Activation Theory of Altruistic Behavior" (Schwartz, 1977) and "Value-Beliefs- Norm Theory - VBN Theory (Stern, 2000) are discussed.

\subsubsection{Norm-Activation Theory of Altruistic Behavior}

Universal value system, which scrutinizes the behavior as a function of beliefs about the consequences of actions and norms about personal responsibility to undertake specific action in response is introduced in this theory (Schwartz, 1977). Activation of a "Personal Norm" is viewed as the important antecedent of pro environmental behavior. When the individual perceives that unfavorable event is occurred with individual well- beings, others well beings and nature through environmental harmful event, norm's activation takes place. In which, personal norms is experienced and considered as the moral obligation to protect the environment form the environmental threats and polluting activities. Thus, theory explicates that the individual's general and environmental value orientations influence the personal norms. Awareness of consequences, awareness of needs, situational responsibility, efficacy, ability and denial of responsibility are the potential antecedents of personal norms. 


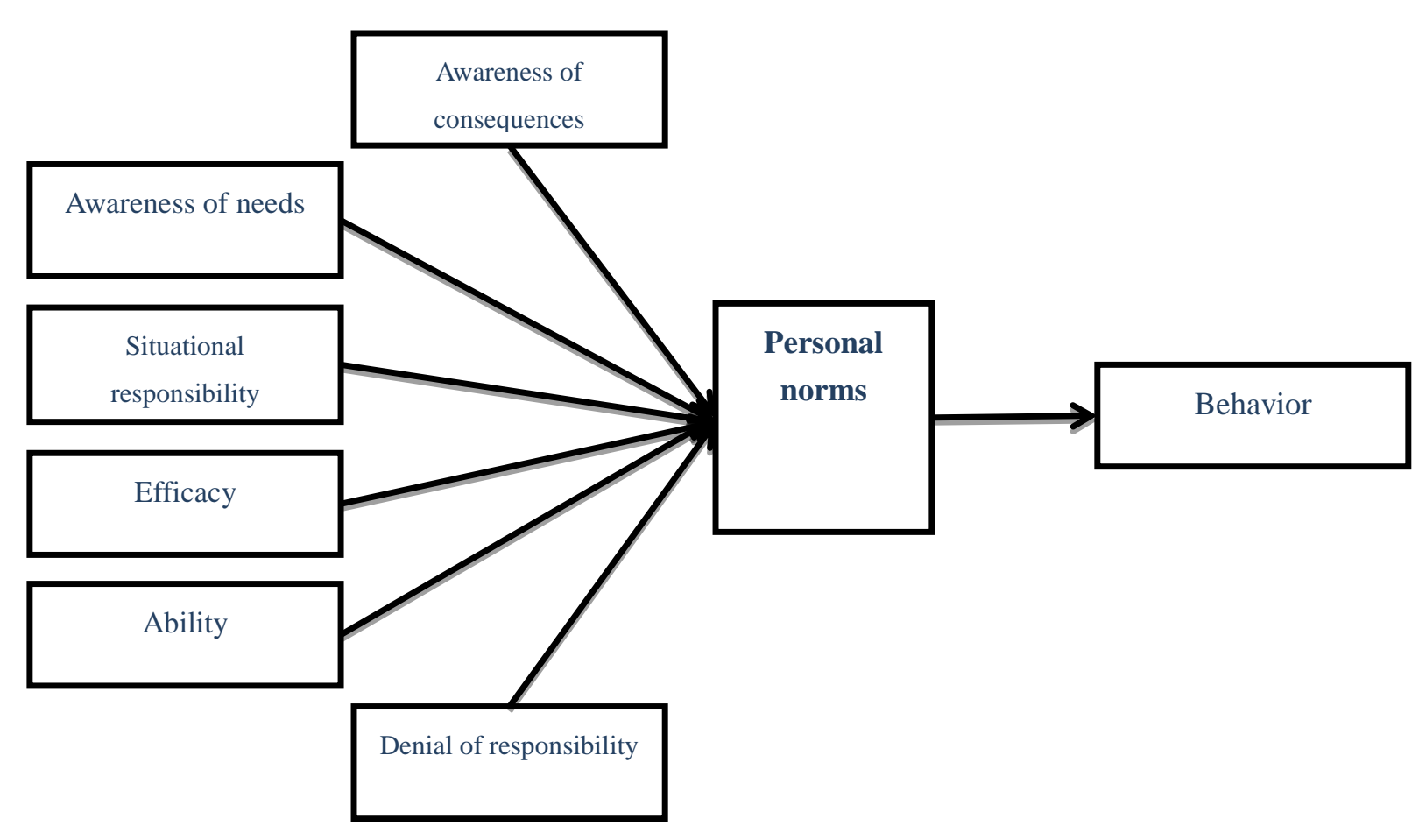

Figure 03: Norm-Activation Theory of Altruistic Behavior

Source: Schwartz, 1977, Norm-Activation Theory of Altruistic Behavior

\subsubsection{Value - Beliefs - Norm Theory - VBN Theory}

Value - Beliefs - Norm Theory - VBN Theory was framed by Stern (2000). This is an extension model for norm-activation theory. This value - belief - norm theory is originally an explanation of altruistic behavior but specially is extended to pro-environmental behavior (Samarasinghe, 2012 b).

According to the previous theories as value theory (Schwartz, 1992), norm-activation theory (Schwartz, 1977) and the new ecological paradigm ( Dunlap et al., 2000), Stern (2000) documents that personal norm is a key determinant that bridges the value action gap as a moral obligation and activates the actual behavior. In which, human value orientation is adopted. And values are categorized in to three constructs as 1) egoistic orientation, which is concerned with the removal of suffering and harm from oneself; 2) altruistic orientation, which is concerned as the social orientation; 3) biospheric orientation is concerned with the removal of destructions and suffering in the non-human world. Those constructs are prerequisite for attitude formation and norms that determine actual behavior. 


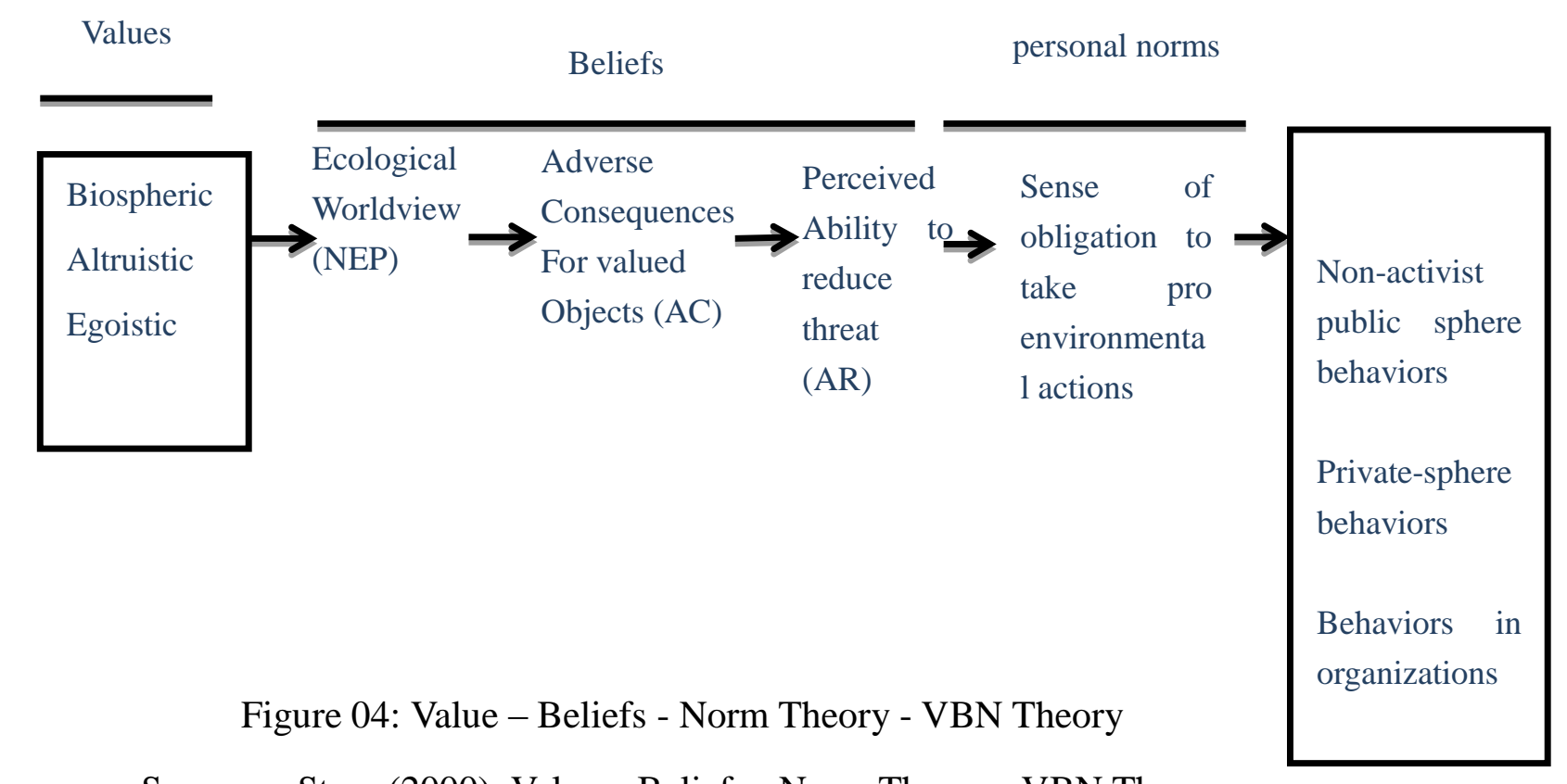

Source: Stern (2000), Value - Beliefs - Norm Theory - VBN Theory

\section{Development of the Conceptual Model of the Study: An Application of Integration Approach}

\subsection{Integrated Model of Green Purchase Intention}

Conceptual Model regarding green purchase intention is constructed to assess the level of intention towards green purchase among young consumers in this study frame. In this stance, Previous theories, models and approaches on the subject of ecological marketing and green consumerisms are used, which enrich the knowledge concerning green consumerism with respect to purchase behavioral intention. In line with above arguments, Theory of Planned Behavior (Ajzen, 1991) and "Value-Beliefs- Norm Theory - VBN Theory (Stern, 2000) are used in this study as the main underpinning theories to construct this model as integrated one to predict the green purchase intention in a strong way, which in turn will lead to purchase behavior. Well known theory as TPB explaining the human behavior and recent theory as VBN theory elucidating the norm as valuable predictor to influence the intention are exploited. In this context, new variable as perceived consumer effectiveness is constructed with the focus on items measuring "perceived behavioral control" in the TPB and items determining "norms" in the VBN Theory to validate the variable further resilient to predict the green purchase intention sturdily.

Furth than, most valuable predictor variables or antecedents of green purchase intention as Environmental Attitude (EA), Environmental Concern ( EC), Perceived Consumer Effectiveness (PCE), Health Consciousness (HC) , Social Influence (SI),MediaInfluence (SMI) and Perceived Government Initiatives (PGI) are identified with previous empirical evidences. Finally, Green Purchase Behavior (GPB) is determined by purchase intention 


\section{Macrothink Institute ${ }^{\mathrm{TM}}$}

( Kollmuss \& Agyeman, 2002; Kim \& Choi, 2005; Jobber, 2007; Lee, 2008; Pickett-Baker \& Ozaki, 2008; Mei et al., 2012; Kaufmann et al., 2012 and Wong et al., 2012).

To this end, model constructed for this study is distinctive. It is based on established theories and models in line with green consumerism. Further, it provides a well-supported explanation for green purchase intention as the integrated model in the green consumerism.

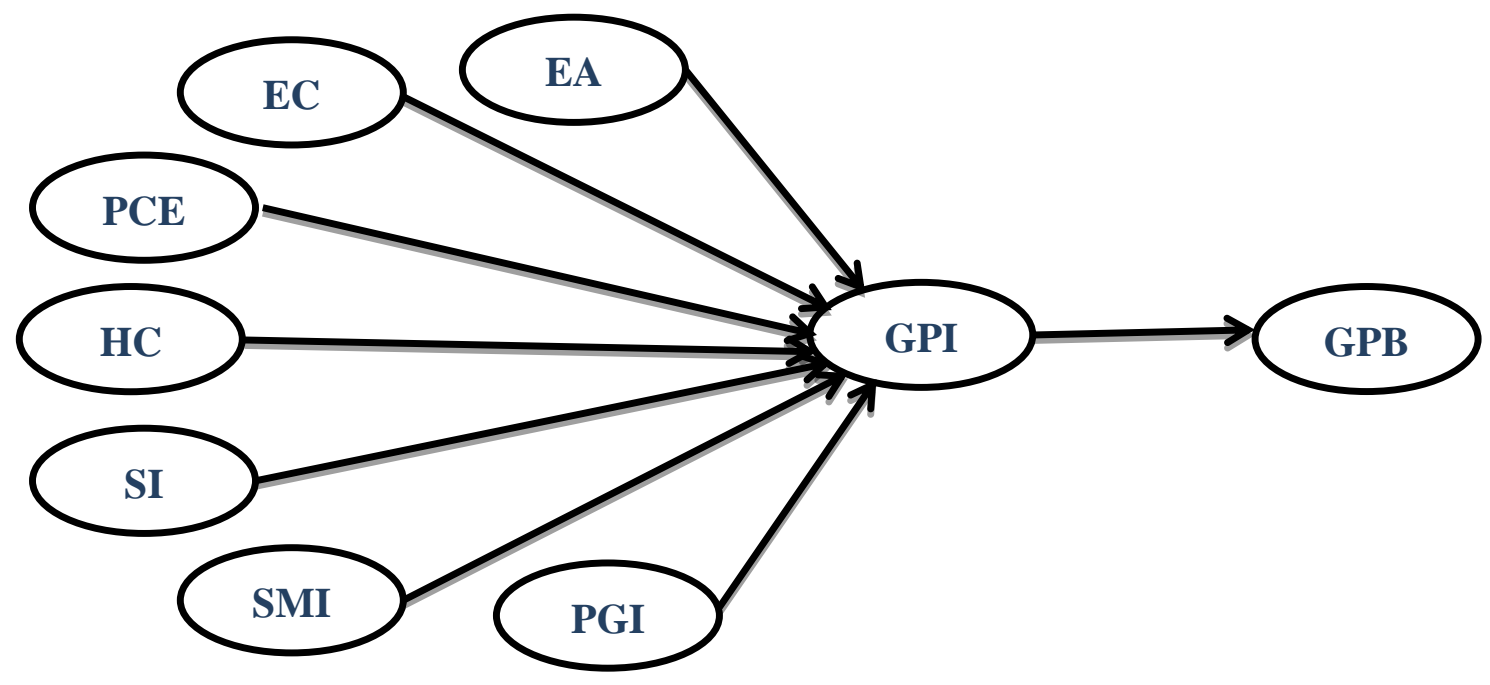

Figure 05: Integrated Model of Green purchase behavioral intention

\subsection{Antecedents of Green Purchase Intention}

\subsubsection{Environmental Attitude (EA)}

Attitude is a person's consistently favorable or unfavorable evaluations, feelings and tendencies toward an object or idea ( Kotler, 2009). In line with this, environmental attitude is defined as "Individuals value judgment of environmental protection, which taps the individuals' cognitive assessment of the value of environmental protection" (Lee, 2008). Environmental attitude is identified as an important predictor of the green purchase intention and behavior in Western and Asian literature (Crosby et al., 1981; Jobber, 2007; Mostafa, 2007; Lee, 2008; Mei et al., 2012; Wong et al., 2012 and Arttachariya, 2012).

\subsubsection{Environmental Concern (EC)}

Environmental Concern refers to beliefs, stance and degree of concern an individual holds toward environment (Said et al., 2003). In supportive view, Lee (2008) points that, environmental concern as the degree of emotional involvement in environmental issues. Previous empirical works document that environmental concern is positively associated with green purchase attitude and its outcomes as intention and behavior ( Antil, 1984; Roberts \& Bacon, 1997; Kim \& Choi, 2005; Lee, 2008 and Kaufmann et al., 2012 ). 


\subsubsection{Perceived Consumer Effectiveness (PCE)}

Perceived consumer effectiveness is the judgment of an individual about the way and the extent of the environmental effects of his or her behavior. Further, it differs from person to person, because of the dissimilarity in individuals' personal knowledge and life experience. Some people have thoughts that, their actions hold evolutionary results whereas others may have little confidence in their abilities to make any difference. In line with this, the relationship and influence between perceived consumer effectiveness and green purchase behavioral intention is documented and supported by previous Western and Asian empirical works (Ellen et al., 1991; Lee \& Holden, 1999; Kim \& Choi, 2005; Chen, 2007; Lee, 2008 and Wong et al., 2012).

\subsubsection{Health Consciousness (HC)}

Health Consciousness assesses the readiness to undertake health actions. People who have health consciousness are aware and concerned about their wellness and motivated to improve and maintain their health, and quality of life to prevent illness by engaging in health behaviors (Newsom et al.2005). In line with this, consumers may have health consciousness and may be ready to do something good for their health and concern about their own health. In nutshell, a healthy lifestyle is generally characterized as a balanced life in which one makes the decisions towards healthy foods and activities. Furthermore, relationship between health consciousness and green purchase behavioral intention is documented positively (Rozin et al., 1999; Sacker et al., 2001; Tarkianen \& Sundqvist, 2005 and Wong et al., 2012).

\subsubsection{Social Influence and Media influence (SI) \& (MI)}

Social norm is whether an action should or should not be performed by respondent in a referents' point of view. Referents could be parents, friends, neighbors, relations etc (Kalafatiset al., 1999). Social influence is derived from the concept as subjective norm in the Theory of planned behavior. It denotes to the perceived social pressure to perform or not to perform the behavior. In addition, mass media and social networks also influence the consumer behavior. Several studies have been conducted on the theme that social influence is the significant predictor variable of green behavioral intention. And, the relationship between those variable are proved and documented in the Western and South Asian literature (De Leon \& Fuqua, 1995; Lee, 2008; Baker \& Ozaki, 2008 and Wong et al., 2012).

\subsubsection{Perceived Government Initiatives (PGI)}

People's perception towards initiative action taken by the national government or the support given by the national government towards sustainable development and environmental protection is referred as perceived government initiatives in the light of green issues (Diekmeyer, 2008). Governments should initiate and promote sustainable events to the community to bring about sustainability awareness to the people (Mei et al., 2012). In line with this, Punitha \& Rahman (2011) document that government's role is another predictor of green purchasing behavior. However, both researchers stress that consumers believe that government should play an important role in building green purchasing. 


\section{Discussion and Conclusion}

In this research work, Green Marketing Strategy: Stake holder theory Perspective (Cronin et al. 2011), Model of Consumer Behavior (Kotler \& Armstrong, 2013), Theory of Reasoned Action and Planned Behavior (Ajzen, 1991), Norm-Activation Theory of Altruistic Behavior (Schwartz, 1977) and Value - Beliefs - Norm Theory (Stern, 2000) were reviewed systematically. Out of those theories, Theory of Planned Behavior underpins the conceptual model of this study. The TPB has been widely used in the general marketing literature to predict consumers' behavior based on their purchase intentions, as this seems to be the best measure of purchase behavior (Park et al. 2005). Also, the TPB can easily be adapted to suit various customer segments and research contexts (Smith et al. 2007; 2008) to provide meaningful practical implications.

Along the line of above arguments, researchers have modified the TPB to explore green purchase intention. The proposed integrated model of green purchase intention encompassed seven factors as antecedents of green purchase intention. Those are environmental attitude, environmental concern, perceived consumer effectiveness, health consciousness, social influence, media influence and perceived government initiatives. Out of seven antecedents, two antecedents as environmental attitude, social influence were conceptualized with the aid of two dimensions in the TPB as attitude and subjective norm respectively. In addition to that, the important antecedent as "perceived consumer effectiveness" was constructed with help of the dimensions as "perceived behavioral control" in TPB and "Personal Norms " in the Value - Beliefs - Norm Theory. In which, perceived control behavior denotes the individual' perceived ability to do the action, while personal norms indicates the feelings of a moral responsible to act. It implies that, consumer' perceived ability to protect the environment and feelings of a moral responsible to act as environmental friendly person tap the consumer mind to act as the effective consumer in green purchasing (Ellen et al., 1991 and Kim and Choi, 2005)

In addition to the three determinants as environmental attitude, social influence and perceived behavior control extracted form TPB, remaining four antecedents as environmental concern, health consciousness, media influence and perceived government initiatives were incorporated in the model. As Suggested by, Kim and Choi (2005) and Lee (2008), Environmental concern was fused in to the model. Fundamental to environmental research is an individual's concern for the environment. Environmental concern denotes an individual's general orientation toward the environment and an individual's concern level on environmental protection (Kim \& Choi, 2005). Further, health consciousness was integrated in to the model with the suggestion from Newsom et al.2005 and Wong et al. 2012. They pointed that, Health Consciousness assesses the readiness to undertake health actions. People who have health consciousness are aware and concerned about their wellness and motivated to improve and maintain their health, and quality of life to prevent illness by engaging in health behaviors. In line with this, generally, person who has health consciousness prefer the green products (Newsom et al.2005 and Wong et al. 2012). 
As Suggested by, Samarasinghe (2012), Media influence was combined into the model. In this context, information shared with the media like mass media (Newspaper and Television) and media(Face Book, Twitter, You Tube etc) greatly take place to spread the information in the globalized level. In line with this, Samarasinghe (2012) pointed that Importance of information in activating values, beliefs and attitudes towards behavior is generally implicitly acknowledged by various scholars in their frame works. Interestingly, researchers in this study used media influence as one of the antecedents explicitly to predict the purchase intention towards green products.

Eventual antecedent as perceived government initiative was integrated in to the model as per suggestions documented by Mei et al (2012). It implies that, People's perception towards initiative action taken by the national government or the support given by the national government towards sustainable development and environmental protection is referred as perceived government initiatives in the light of green issues (Diekmeyer, 2008). To this end, this model is dynamic and comprehensive in nature. This model might be applied in globalized level to predict green purchase intention and behavior.

\section{References}

Aertsens, J., Verbeke, W., Mondelaers, K., \& Van Huylenbroeck, G. (2009). Personal determinants of organic food consumption: a review. British Food Journal, 111(10), 1140-1167.

Ajzen, I. (1991). The theory of planned behavior. Organizational Behavior and Human Decision Processes, 50, 179-211.

Ajzen, I., \& Driver, B. L. (1992). Application of the theory of planned behavior to leisure choice: Journal of Leisure Research, 24(3), 207-224.

Antil, J. H. (1984). Conceptualization and operationalization of involvement.Advances in consumer research, 11(1), 203-209.

Ariff, A.H.M., Bidin, Z., Sharif, Z., \& Ahmad, A. (2010). Predicting entrepreneurship intention among malay university accounting students in malaysia: European Journal, $6,1-10$.

Arttachariya, P. (2012). Environmentalism and Green Purchasing Behavior: A Study on Graduate Students in Bangkok, Thailand. Assumption University, Thai Land.

Arvola, A., Vassallo, M., Dean, M., Lampila, P., Saba, A., Lähteenmäki, L., \& Shepherd, R. (2008).Predicting intentions to purchase organic food: The role of affective and moral attitudes in the Theory of Planned Behaviour. Appetite,50(2), 443-454.

Baker, J., \& Ozaki, R. (2008). Pro-environmental products: marketing influence on consumer purchase decision. Journal of consumer marketing,25(5), 281-293.

Beckford, C. L., Jacobs, C., Williams, N., \&Nahdee, R. (2010). Aboriginal environmental wisdom, stewardship, and sustainability: Lessons from the Walpole Island First Nations, 
Ontario, Canada. The journal of environmental education, 41(4), 239-248.

Chan, R. Y. (2001). Determinants of Chinese consumers' green purchase behavior. Psychology \& Marketing, 18(4), 389-413.

Chan, R. Y., \& Lau, L. B. (2000). Antecedents of green purchases: a survey in China. Journal of consumer marketing, 17(4), 338-357.

Chen, M. F. (2007). Consumer attitudes and purchase intentions in relation to organic foods in Taiwan: Moderating effects of food-related personality traits. Food Quality and Preference, 18(7), 1008-1021.

Cronin Jr, J. J., Smith, J. S., Gleim, M. R., Ramirez, E., \& Martinez, J. D. (2011). Green marketing strategies: an examination of stakeholders and the opportunities they present. Journal of the Academy of Marketing Science,39(1), 158-174.

Crosby, L.A., Gill, J.D. \& Taylor, J.R., 1981.Consumer voter behaviour in the passage of the Michigan container law. The Journal of Marketing, 19-32

De Leon, I. G., \& Fuqua, R. W. (1995).The effects of public commitment and group feedback on curbside recycling. Environment and Behavior, 27(2), 233-250.

Diekmeyer, P. (2008). Bribery in public procurement: protecting your company from corruption.

Dunlap, R. E., Van Liere, K. D., Mertig, A. G., \& Jones, R. E. (2000). New trends in measuring environmental attitudes: measuring endorsement of the new ecological paradigm: a revised NEP scale. Journal of social issues, 56(3), 425-442.

Eisenberg, N., \& Miller, P. A. (1987). The relation of empathy to prosocial and related behaviors. Psychological bulletin, 101(1), 91.

Ellen, P. S., Wiener, J. L., \& Cobb-Walgren, C. (1991).The role of perceived consumer effectiveness in motivating environmentally conscious behaviors.Journal of Public Policy \& Marketing, 102-117.

Hannan, M. T., \& Freeman, J. (1984).Structural inertia and organizational change.American sociological review, 149-164.

Jobber, D. (2007) Principles \& Practice of Marketing, 5th ed. Maidenhead, McGraw-Hill

Johri, L. M., \&Sahasakmontri, K. (1998).Green marketing of cosmetics and toiletries in Thailand. Journal of Consumer Marketing, 15(3), 265-281.

Kalafatis, S. P., Pollard, M., East, R., \&Tsogas, M. H. (1999). Green marketing and Ajzen's theory of planned behaviour: a cross-market examination. Journal of consumer marketing, 16(5), 441-460.

Kaufmann, H. R., Panni, M. F. A. K., \&Orphanidou, Y. (2012). Factors affecting consumers' green purchasing behavior: An integrated conceptual framework. Amfiteatru Economic, 15(31), 50-69. 
Kim, Y. and S. M. Choi (2005), “Antecedents of Green Purchase Behavior: An Examination of Collectivism, Environmental Concern, and PCE," Advances inConsumer Research, 32, 592-599.

Kollmuss, A. \&Agyeman, J. (2002) . Mind the gap: why do people act environmentally and what are the barriers to pro-environmental behavior?.Environmental Education Research, $8(3), 239-260$.

Kotler, P. (2009). Marketing management: A south Asian perspective. Pearson Education India.ics, 32(1), pp. 93-107.

Kotler, P., \& Armstrong, G. (2013). Principles of Marketing 15th Global Edition. Pearson.

Kotler, P., \& Keller, K. L. (2006).Marketing management. 12th (ed.). Upper Saddle River, NJ: Pearson Prentice Hall Inc.

Lee, J. A., \& Holden, S. J. (1999).Understanding the determinants of environmentally conscious behavior. Psychology and Marketing, 16(5), 373-392.

Lee, K. (2008). Opportunities for green marketing: young consumers. Marketing intelligence \& planning, 26(6), 573-586.

McCarty, J. A., \&Shrum, L. J. (2001).The influence of individualism, collectivism, and locus of control on environmental beliefs and behavior. Journal of Public Policy \& Marketing, 20(1), 93-104.

Mei, O. J., Ling, K. C., \&Piew, T. H. (2012).The Antecedents of Green Purchase Intention among Malaysian Consumers. Asian Social Science, 8(13).

Mostafa, M. M. (2007). Gender differences in Egyptian consumers' green purchase behaviour: the effects of environmental knowledge, concern, and attitude. International Journal of Consumer Studies, 31(3), 220-229.

Mostafa, M., 2009. Shades of green: A psychographic segmentation of the green consumer in Kuwait using self organizing maps. Expert Systems with Applications, 36(8), 11030-11038.

Mostafa, M.M. (2007). Gender differences in Egyptian consumers green purchase behavior: The effects of environmental knowledge, concern and attitude. Int. J. Consumer Stud., 31: 220-229.

Newsom, J. T., McFarland, B. H., Kaplan, M. S., Huguet, N., \&Zani, B. (2005). The health consciousness myth: implications of the near independence of major health behaviors in the North American population.Social Science \& Medicine, 60(2), 433-437.

Ohtomo, S., \& Hirose, Y. (2007). The dual-process of reactive and intentional decision-making involved in eco-friendly behavior.Journal of Environmental Psychology, 27(2), 117-125.

Peattie, K. and Crane, A. (2005), “Green marketing: legend, myth, farce or prophesy?", Qualitative Market Research, 8 (4,). 357-370. 


\section{Al Macrothink}

Journal of Sociological Research ISSN 1948-5468 2016, Vol. 7, No. 1

Pickett-Baker, J., \& Ozaki, R. (2008). Pro-environmental products: marketing influence on consumer purchase decision. Journal of consumer marketing,25(5), 281-293.

Roberts, J. A., \& Bacon, D. R. (1997).Exploring the subtle relationships between environmental concern and ecologically conscious consumer behavior.Journal of Business Research, 40(1), 79-89.

Rozin, P., Fischler, C., Imada, S., Sarubin, A., \&Wrzesniewski, A. (1999). Attitudes to food and the role of food in life in the USA, Japan, Flemish Belgium and France: Possible implications for the diet-health debate.Appetite, 33(2), 163-180.

Sacker, A., Bartley, M., Firth, D. \& Fitzpatrick, R. (2001), "Dimensions of social Inequality in the health of women in England: occupational, material and behavioral pathways", Social Science and Medicine, 52 (5), 761-81.

Samarasinghe, R. (2012 a). Green Consumerism: Individual's Ethics and Politics as Predictors of Pro-Environmental Behaviour. Delhi Business Review,13(1), 41-48.

Samarasinghe, R . (2012 b) .Is Social Psychological Model Sufficient: Empirical Research Gaps for understanding Green Consumer Attitudinal Behavior.International Journal of Advanced Research in Management and Social Sciences, 1 (4), 28-54.

Samarasinghe, R. (2012 c). The Influence of Cultural Values and Environmental Attitudes on Green Consumer Behavior. International Journal of Behavioral Science, 7(1), 83-98.

Schwartz, S. H. (1977). Normative influences on altruism. Advances in experimental social psychology, 10, 221-279.

Stern, P. C. (2000). New environmental theories: toward a coherent theory of environmentally significant behavior. Journal of social issues, 56(3), 407-424.

Smith, J. R., Terry, D. J., Manstead, A. S. R., Louis, W. R., Kotterman, D., \& Wolfs, J. (2007). Interaction Effects in the Theory of Planned Behavior: The Interplay of Self-Identity and Past Behavior. Journal of Applied Social Psychology, 37(11), 2726-2750.

Smith, J. R., Terry, D. J., Manstead, A. S. R., Louis, W. R., Kotterman, D., \& Wolfs, J. (2008). The Attitude-Behavior Relationship in Consumer Conduct: The Role of Norms, Past Behavior, and Self-Identity. Journal of Social Psychology, 148(3), 311-334.

Tarkiainen, A., \&Sundqvist, S. (2005). Subjective norms, attitudes and intentions of Finnish consumers in buying organic food. British Food Journal,107(11), 808-822.

Wong, F. V., Lee, M. Y., Lin, X. R., \& Low, S. Y. (2012). A study on the youth attitude toward purchase green products in Malaysia \& Singapore (Bachelor dissertation, UTAR).

\section{Copyright Disclaimer}

Copyright for this article is retained by the author(s), with first publication rights granted to the journal.

This is an open-access article distributed under the terms and conditions of the Creative 

2016, Vol. 7, No. 1

\footnotetext{
Commons Attribution license (http://creativecommons.org/licenses/by/3.0/).
} 